\title{
MIXED LANGUAGES AS OUTCOMES OF CODE-SWITCHING: RECENT EXAMPLES FROM AUSTRALIA AND THEIR IMPLICATIONS ${ }^{1}$
}

\author{
Patrick McConvell
}

AIATSIS, Canberra

\section{Introduction}

The output of code-switching often bears a significant resemblance to the patterning of mixed languages. A number of scholars have proposed as a theoretical possibility that code-switching could have a mixed language as an outcome as the patterning is conventionalised by language learners. Bakker (2003:129) however claims that 'mixed languages' do not arise from codeswitching. The general opinion has been that there are no documented examples of such a process. This paper briefly describes one documented example of the recent emergence of a mixed language from code-switching: Gurindji Kriol (McConvell \& Meakins 2005, Meakins 2007b) and there appear to be other similar examples in Australia. These are new hybrid languages which have grown out of a mixture of the grammar and lexicon of traditional Indigenous languages and of an Aboriginal English/Creole variety (Kriol). Code-switching was pervasive in adult Gurindji speech in the 1970's and this provided the main input to children's first language acquisition at the time.

This paper shows that the dominant patterns of distribution of items from the Kriol source and the Gurindji source in the mixed language reflect the patterning in the code-switching of the previous generation.

If at least some mixed languages arose from code-switching then the principles of hybridisation of mixed languages in such cases is likely to be largely predictable from code-switching constraints, e.g. those proposed by Carol Myers-Scotton, the Matrix Language Framework theory, (1993) subsequently elaborated into the 3-M theory (2002).

However one of the features of Gurindji Kriol also found in a number of other hybrid languages in Australia and elsewhere (including Michif) is what has been termed a Verbal-Nominal split. In this type, one of the component languages dominates verbal and tense-aspect-mood syntax,

\footnotetext{
${ }^{1}$ I wish to thank the Gurindji people who taught me about their language, culture and history over many years. I am also especially indebted to Felicity Meakins for freely sharing ideas and data with me from her work with the Gurindji on the Aboriginal Children's Language Acquisition project. The ideas presented here are not necessarily the same as hers.
} 
morphology and in some cases lexicon, and the other language dominates nominal syntax, morphology, and in some cases lexicon. Although Myers-Scotton recognises that the process of 'turn-over' of one Matrix-language to another can halt before completion, and acknowledges this type of split language (2002), her code-switching theory does not directly address the reasons why this particular split is commonly found. McConvell (1997a, 2002) has proposed that the V-N split relates to the grammatical typology of the 'old' source language-where it is dependent-marking like Gurindji, then a split in which nominal grammar is retained from the old language is predicted; and where it is head-marking, then retention of verbal grammar from the old language is predicted. This proposal is assessed and modified here,with the notion of a 'verbal-nominal' split being replaced by a split between elements linked to I(NFL), and the rest of the clause (cf. Matras' (2003) notion of INFL-language).

The proposal that mixed language hybridity principles can arise from code-switching constraints based on the typology of the interacting languages, obviously could have strong implications for our view of linguistic prehistory. It is not possible to do justice to this broad issue in this paper, but one could predict what languages which have been created by this kind of process in the past would look like, with a view to finding some languages which match these criteria.

The aims of this paper are as follows:

1) to show that a transition from code-switching between two languages to a mixed language has been empirically demonstrated in at least one case;

2) following on that, to examine whether the constraints proposed to account for codeswitching may also play a role in explaining the composition of hybrid languages;

3) to critically examine a proposal based on the typology of the old language (the 'Centre of Gravity' Hypothesis) which seeks to explain code-switching patterns and the hybrid languages which are their outcomes;

4) to propose a further explanation of the 'Centre of Gravity' Hypothesis in which the location of INFL components of a clause determines which languages dominate which parts of a clause in hybrid outcomes.

There are more broad aims which might be followed up, but this assumes a larger project than can be attempted in this paper:

5) to plot what kinds of outcomes would be present in languages if the hypothesised processes been active in the past history of language contact, with a view to finding such patterns in attested languages.

It is not clear that the relevant outcomes are indeed outcomes of code-switching in all cases, Another strand in the investigation would be

6) to determine whether there are particular types of language contact interaction, including both code-switching and other kinds, which bring about distinct outcomes.

Investigation of the so-called Verbal-Nominal and INFL split languages may help us to build a theory of language composition-how composite varieties are formed-,and recognize the signatures of this kind of 'arrested turnover' in the past in attested languages. 


\section{Gurindji Kriol}

\subsection{The emergence of the new mixed language}

Gurindji is an Australian Aboriginal language of the Pama-Nyungan family, Ngumpin-Yapa subgroup (McConvell \& Laughren 2004). Since the 1880's Europeans have been entering the savannah of the north-central Northern Territory where they lived. Gurindji people were forced to live and work on cattle stations and learned the English-based Cattle Station Pidgin as an additional language, which they used for wider communication with whites and other Aborigines of different language groups. This pidgin (known as Kriol) began to be adopted as a first language by some groups in the Northern Territory from about 1910, and in the region around the Gurindji from around 1950.

Gurindji code-switching of the older generation, which was the dominant form of speech in the community in the 1970's, was recorded and partially described by McConvell (1988). In the 1970's most Gurindji people over the age of 20-25 were fluent in both Gurindji, the traditional language of the group, and Kriol. In the code-switching form of speech there was alternation between Gurindi and Kriol, an English-based regional lingua franca, but the question of the matrix language had not been settled. (Dalton et al. 1995, McConvell 2002). Even at that stage however there was a tendency for Kriol to be the matrix language and to provide the syntactic ordering and tense-aspectmood functions. Case-marking of NP's and other mainly nominal morphology was retained in Gurindji. Lexical (content) items were drawn from both languages, including many of the Gurindji coverbs (uninflecting elements usually occurring with inflecting verbs in Gurindji) taking the role of verbs in the new mixed language, Gurindji Kriol

This code-switching style, and particularly this default pattern of split, was stabilized into a mixed language, Gurindji Kriol, as children acquired it as their first language in the 1960's-80's. This was decribed by Gurindji speakers working with McConvell, Dalton et al. (1995, termed 'Gurindji Children's language'); Charola (2002); and ongoing work by Felicity Meakins (e.g. Meakins 2007) to whom I am indebted for some of the data in this paper.

The patterns of Gurindji Kriol mixed language are due to the most frequent and salient input to child learners from adults in the 1960's-80's being Gurindji-Kriol code-switching, combined with declining proficiency in traditional Gurindji among most young people. In Gurindji Kriol, traditional Gurindji pronominal enclitic marking and inflecting verbs with their inflections were lost.

The language spoken most frequently by Gurindji people between the ages of 3 and about 45 today, termed 'Gurindji Kriol' here, is a counter-example to Bakker's generalization (2003:129) that mixed languages do not arise from code-switching.

Gurindji Kriol exhibits a split between what might be termed verbal and nominal systems, as do other mixed languages like Michif. In fact as is argued below, the split is actually between the Tense-Aspect-Mood (TAM) system, characterized by what used to be called I or INFL (head of IP) in Chomskyan generative grammar. Depending on the language type-whether TAM/INFL is fully expressed within the verb or not—-this will manifest itself as 'verbal' or not.

However, the source language for each component is the reverse of Michif, where the old language, Cree, is the source of the verbal system and the new language, French, the source of nominal systems. In Gurindji, basic verbs such as 'go' and 'sit', the tense-aspect-mood system and transitive morphology are derived from Kriol, whereas emphatic pronouns, possessive pronouns, case markers and nominal derivational morphology have been transplanted from Gurindji relatively intact, but with some innovations. Demonstratives, nouns, verbs and adpositions are adopted from both languages, however some generalisations can be made about their distribution. The coverbs of Gurindji compound verbs can appear in Gurindji Kriol as verbs. 
The following short excerpt of a Gurindji Kriol story (1) illustrates some of these features. Gurindji elements are in italics; other elements are drawn from Kriol.

(1) Gurindji Kriol (McConvell 2002 \& Meakins 2005)

(a) nyawa-ma karu bin plei-bat pak-ta nyanuny warlaku-yawung-ma. this-TOP one child PST play-CONT park-LOC 3sg.DAT dog-HAVING-TOP 'This one kid was playing at the park with his dog.'

(b) tu-bala bin plei-bat. i bin tok-in la im two-NUM PST PST play-CONT. 3sg PST talk-PROG PREP 3sg

'The two of them were playing and the kid said to him:'

(c) "kamon warlaku partaj ngayiny leg-ta... come.on dog go.up 1sg.DAT leg-LOC

، “Come on dog jump up on my leg ...'

(d) ngali plei-bat nyawa-ngka.”

1sg.inc play-CONT this-LOC

You and me can play here.””

In this excerpt, most of the verb phrase morphology is derived from Kriol - past tense bin, continuative -bat; -in'from English '-ing' was not originally part of the regional Kriol but is now being incorporated. Elements from Gurindji are emphatic pronouns such as ngali, possessive pronouns nyanuny, locative markers -ta, proprietives -yawung and demonstratives nyawa. Both languages contribute content words - Gurindji: warlaku, karu, partaj; and Kriol: 'plei', 'tok', 'leg'. Partaj ' 'go up' is a coverb. which usually occurs with a verb, e.g. partaj yanta 'go.up go', although use of a coverb alone in an impertative is also greammatical in traditional Gurindji.

Within words and phrases from a Gurindji source, the grammar does not necessarily match the old Gurindji exactly. For instance traditionally nyawa-ngka would have been murla-ngka with a suppletive stem for 'this, here' when case-marked. In traditional Gurindji too, case marking and some derivational marking (like the proprietive -jawung -yawung) would spread across all elements of the noun phrase so for instance ngayiny in 1(c) above would have been ngayiny-ja 'myLOC' in agreement with the following noun, and in 1(a) nyanuny would have been nyanyunyjawung 'my-HAVING' in agreement with the following noun.

In the case of Gurindji Kriol, the mixed language exists independently of Gurindji or Kriol. Socially, it is the language of everyday use, and may be found in a large number of domains, including the home, community shop, and council office. Gurindji is only found in the home, spoken conversationally by older people, in traditional ceremony and some Christian ceremonies. Younger Gurindji Kriol speakers generally do not speak Gurindji although they may understand it to some extent. Kriol, without Gurindji mixing, is not used at all within the community but may be used with Aboriginal people from other groups. English now occupies the official domains such as meetings and schooling.

Gurindji Kriol is now the native and predominant language of an entire community, and is spreading beyond that community. Whether they are of 'mixed' parentage or not, speakers do not identify themselves as an ethnic group separate from the Gurindji, and usually call the language they speak 'Gurindji'. In this respect they are like Mednyj Aleut speakers (Matras \& Bakker 2003: 3). For further argument about why Gurindji Kriol should be considered a 'mixed language' see 
McConvell \& Meakins (2005).

\subsection{Structure of the split in the code-switching stage}

Conversational speech between men of the age range of 25-60 in 1977 was divided as follows. The top row of percentages shows the proportion of clauses in text which are solely in one language or another or mixed: the result is approximately one third of each type. The second row of percentages shows the proportion of clauses with Gurindji and Kriol Matrix Language within the mixed clause category: here the result is approximately two-thirds Kriol ML and one-third Gurindji ML. This is significant in that the mixed language outcome in the next generation is based on a Kriol ML structure.

(2) Table : Proportion of different languages in adult code-switching text ${ }^{2}$

\begin{tabular}{|l|l|l|l|}
\hline Language & Gurindji & Kriol/English & Mixed \\
\hline Percentage of clauses & $36 \%$ & $31 \%$ & $33 \%$ \\
\hline \multicolumn{2}{|l|}{ ML’s in mixed clauses } \\
\hline ML & Gurindji & Kriol & Ambiguous \\
\hline Percentage & $28 \%$ & $60 \%$ & $12 \%$ \\
\hline
\end{tabular}

Code-switching (CS) in Gurindji includes cases of an alternational switch between clauses as in (3). As in this case this may have expressive force-as here the first clause in Kriol is part of the discourse of the cattle station but the second in Gurindji has to do with community and kinship concerns. ${ }^{3}$ Note the subject and object pronominal enclitics hosted by the complementizer and the verb with tense-aspect inflections in the Gurindji clause.

\section{(3) Kat-im ros ram jak ngara=ngala=ngkulu yarriyi marn-ana cut TRN roast, rump, chuck LEST 1 pl.O 3 pl.S grumble say PRES}

'Cut the roast, rump and chuck so they don't grumble about us.'

This type of switch is not dealt with here, only switches within the clause which relate to the pattern found in Gurindji Kriol. Prime among these are sentences like (4)

(4) Kaa-rni-mpal said orait yutubala kat-im ngaji-rlang-kulu. east-UP-ACROSSside alright 2DU cut-TRNfather-DYAD-ERG 'You two, father \& son, cut it across the east (side of the cow).'

\footnotetext{
${ }^{2}$ Of the mixed clauses, most clearly have either Gurindji or Kriol as the Matrix language- the language which controls the morphosyntactic frame. As a rule of thumb, those clauses with Kriol tense-aspect-mood elements such as the past auxiliary 'bin' have Kriol ML and those with Gurindji auxiliaries, pronominal enclitics and TAM inflections on the verb have Gurindji ML. With copular clauses, with no verb, the decision is sometimes not so clear, and these have been noted as 'ambiguous'.

${ }^{3}$ The complementizer ngara is from the Wanyjirra dialect in contrast to the more regularly used form ngaja. For the social function of dialect switching see McConvell (1988).
} 
The feature which shows that the matrix language here is Kriol is the pronoun yutubala. If the sentence had been as follows with a Gurindji verb with an imperative inflection followed by a dual subject enclitic, it would be an example of code-switching with a Gurindji matrix.

(5) Kaa-rni-mpal said orait east-UP-ACROSS side alright kat-im parra=wula ngaji-rlang-kulu.

2DU cut-TRN hit DU S father-DYAD-ERG

'You two, father and son, cut it across the east (side of the cow).'

This is an invented example but actual examples like this occur in CS text of the 1970's e.g.

(6)

$\begin{array}{llll}\text { niyan } & \text { kat-im } & \text { pa-rr-a-yi } & \text { ngapu. } \\ \text { flesh cut-TRN } & \text { hit-IMP-1SG.O } & \text { father }\end{array}$

'Cut the meat for me father.'

Here the ancillary verb has an imperative inflection $r r a$ and a first person singular object enclitic (crossreferencing beneficiary).

Returning to (4), note that the initial directional expression and the final transitive subject NP are in Gurindji, the latter having two Gurindji suffixes one semantic (or 'early system' in MyersScotton's terms) and the ergative case suffix ('later outsider system' in Myer-Scotton's terms as it has a grammatical function relating to the NP's function in the clause). In Myer-Scotton's terms these would be 'embedded language islands' as the general constraints she proposes for 'classic' code-switching would demand Kriol morphology in a Kriol-matrix sentence.

This is not however simply an aberrant insertion of a chunk of Gurindji; this is part of a regular patterning of the majority of CS - NP's are very frequently case-marked including with ergative in Kriol matrix clauses. In the case of the mixed language Gurindji Kriol, ergative marking is not found in all examples, but the language of the NP concerned seems irrelevant. In the 1970's codeswitching there appears (from the small number of examples available) to be a tendency for the Gurindji NP's to take ergative but the Kriol NP's not to. So the example (7) is from a text but the constructed example (8) may have been unacceptable. ${ }^{4}$

(7) Igulok, that wan bin faind-im

(8) ? Igulok, that wan-tu bin find-im

Eagle hawk that one ERG PST faind TRN

However, Gurindji case-marking is found on Kriol NP’s in Kriol ML clauses in the CS data, as in (8) — significantly perhaps from a younger man.

(9) chikin faul - $u$ they want-im nek bif

chicken fowl DAT they want TRN neck beef

'They want neck beef for the chickens.'

\footnotetext{
${ }^{4}$ Felicity Meakins (pers.comm.) finds no examples like (8) in the Gurindji Kriol data but interprets this as arising from a constraint against Gurindji case marking on Kriol demonstratives.
} 
The use of Gurindji ergative suffixes is not confined to post-verbal position in CS data; it is also found in pre-verbal position as in

(10) onli jintaku-lu Warlawurru-lu bin faind-im nyawa na

only one ERG Eagle ERG PST find TRN this now

'Only the one Eagle found this one.'

\subsection{The split in Gurindji Kriol}

The kinds of grammatical pattern seen above in 1970's CS are reproduced with little change in the new mixed language. In (11) there is a post-verbal transitive subject NP with ergative marking and (12) and (13) exemplify preverbal ergatively marked subjects followed by two variants of the Kriol subject pronoun im and $i$ bin (Meakins 2007a, b) ${ }^{5}$
(11) an skul-ta-ma jei bin
'And the kids had sport at school.'
hab-im
sport karu-walija-ngku.
and school-LOC-TOP3PL.S PST have-TRN
sport child-PAUC-ERG
(GK ML: FM060.A: LS20yr: Conversation)
(12) kirri-ngku il=m kil-im-bat ngarlu.
woman-ERG 3SG.S-NF hit-TRN-CONT honey
'The woman hit the hive in order to get honey.'
(FHM064: RR23yr: Ergative bingo)

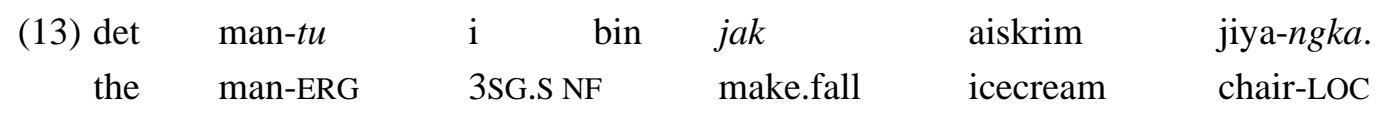
'The man spilt the icecream on the chair.'
(FHM053: SS18yr: Locative pictures)

However this Kriol subject pronoun is not required in the Gurindji Kriol as the next example shows

(14) paka -ngku turrp nyantu kuya -ny -ta

prickle ERG pierce 3 SG thus KIND LOC

'The thorn is prickin him on this kind.'

(FM046.B.cha FRR)

The object pronoun in (14) is the Gurindji free pronoun; alternatively the Kriol pronoun can be

\footnotetext{
${ }^{5}$ In (13) note the Kriol NP with Gurindji ergative case suffix which may be an innovation, as noted above. Another innovation in GK is the final placement of the ergative suffix in the NP; in traditional Gurindji and the 1970's code-switching, each element of the NP is case-marked as in (10).
} 
used as in (15)

(15) paka-ngku turrp im fut-ta

prickle-ERG poke 3sG foot-LOC

'The thorn s pricking him in the foot.'

The Gurindji free pronouns can also appear as subjects with ergative marking on Gurindji Kriol. unlike in traditional Gurindji where they are not case-marked.

This was first noticed by Dalton et al. (1995) and in McConvell \& Meakins (2005) it is observed that the use of Gurindji subject pronouns without Kriol pronominal elements is perhaps becoming functionally differentiated from forms with Kriol pronominal elements, in signalling contrast as in (16). This provides a clue to the shift in the analysis of this case marker, which later begins to be used sometimes as a contrast marker even when not suffixed to transitive subjects.

(16) ma yu purrum kuya ngayu-ngku purrum kuya

DIS 2SG put TRN thus 1SG-ERG put.TRN thus

'You put it like this, I put it like this.'

\subsection{The transition in terms of the MLF/ 3-M Model}

Myers-Scotton and colleagues have provided a model of the process which can lead from 'classic' code-switching to a mixed (what she calls 'split') language (Myers-Scotton 2002). The crucial intermediate stage is the development of 'composite' code-switching where the constraints on insertions are no longer strictly adhered to and elements 'split and recombine', so that system morphemes from both contributing languages can be found. At the same time though, this composite can become more fixed in its structure and the distribution of elements from component languages, as it becomes more like a single language.

In the initial stage of 'classic' code-switching, cases of system morphemes from the embedded (non-matrix) language must be in EL (embedded language) islands. Myers-Scotton (1993: 137) has provided a list of items which are most likely to form such islands.

1. $\quad$ Formulaic expressions and idioms (especially time and manner PPs but also as VP complements)

2. $\quad$ Other time and manner expressions (NP/PP adjuncts used adverbially)

3. Quantifier expressions (APs and NPs especially as VP complements)

4. $\quad$ Non-quantifier, non-time NPs as VP complements (NPs, APs, CPs)

5. $\quad$ Agent NPs

6. Thematic role- and case-assigners, ie main finite verbs (with full inflections)

In the 'composite' stage some of the EL system morphemes enter the composite ML, in a process of convergence. It is fair to say that this area of how language composition takes place remains undertheorised. 
The way Myers-Scotton talks about the relationship between the languages is also somewhat at odds with what occurred with Gurindji and probably other language pairs

the waning language loses its undisputed role as the source of the Matrix language in bilingual CP's (2002:101)

In the Gurindji case it is not simply a case of the old language Gurindji 'waning' but the new language Kriol actually taking over the main ML role but leaving some elements of structure as dominated by the old language Gurindji. This kind of process is also recognised by Myers-Scotton as taking place in mixed language genesis e.g. for Mednjy Aleut.

The reasons given for the formation of a composite ML (Myers-Scotton 2002:105) in terms of limited access to the morphosyntactic frames of the 'desired source' are difficult to understand and probably irrelevant to the Gurindji case. It seems to be based on a model of an old language providing the ML in the first instance and speaker 'desiring' to add elements of a new language, whereas in the Gurindji case the new language takes over as the ML early on but some regions of structure are protected or blocked from turnover. The alternative reason given, that the 'notion of a target ML is not clear to the speakers' is perhaps slightly more relevant.

Myers-Scotton (2002:247-248) sees split (mixed) languages as also having a composite ML.

... some surface level late system morphemes come from the 'other language' involved in the compound (if CS is involved this 'other' language is the 'old' EL)...when some of the late outsider morphemes come from the EL it is implicational evidence that the morphosyntactic frame has changed;... taking in system morphemes from that second language.

Again the issue referred to above is apparent: in the Gurindji situation the EL late system morphemes being brought in are from Gurindji, like the case-markers, as the ML in terms of the TAM system has already moved to Kriol.

Myers-Scotton (2002:249) provides an overall model for mixed language genesis which is useful:

split [mixed] languages represent turnovers that do not go to completion but 'stop along the way' : where they stop partly determines the form they show today. For this reason the varieties that are called mixed languages are indeed a mixed bag. In different split languages splits are found in different places.

As the latter part of this quotation shows however there seems to be some idea that the number of types of mixed languages would be very large as all kinds of interactions take place. The aim of this paper is to try to tighten up the theory of composition and mixed language genesis so that there is only a limited number of possible outcomes, and these are predictable from structural types of the interacting languages.

Myers-Scotton seems to persist with the idea that the prototypical split languages are those with a lexicon-grammar split (249, 271) — the 'structural prototype' which is questioned by Matras (2003). However those which fall within the 'less stringent' definition are more relevant to our Australian examples where lexicon/grammar is hardly an issue

a major constituent with its system morphemes and major parts of its ms frame from a different source language from that of most of the lexicon and the ms frame of other constituents

Myers-Scotton argues strongly that code-switching is involved in all or most mixed language genesis, although cogent evidence is not available for many cases.

Diagram (17) summarises the relevance of Myers-Scotton's models for the case of Gurindji /Kriol code-switching turning into the mixed language Gurindji Kriol. The kind of case MyersScotton appears to focus on as prototypical is (b) where the Matrix Language is and remains the Old 
language of the community of speakers. The process of turnover begins by some constituent of the clause opening up to organisation in terms of the other-in this case New language-in particular allowing late system morphemes to be used in this region of the clause. The case of Gurindji is much the same except that the relevant point of departure is after the turnover to the new language Kriol as ML has been accomplished at least in the bulk of code-switching discourse. However the old language Gurindji retains dominance of the morphosyntactic frame of a part of the clause, in this case mainly the NP, allowing use of the late system morphology such as case-markers. ${ }^{6}$

(17)Diagram: formation of a composite ML

(a) Gurindji: New Language ML

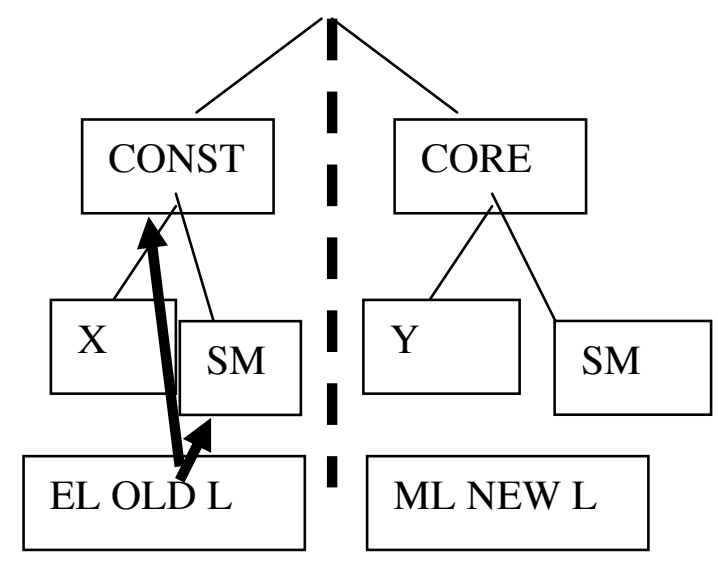

(b) Old Language ML

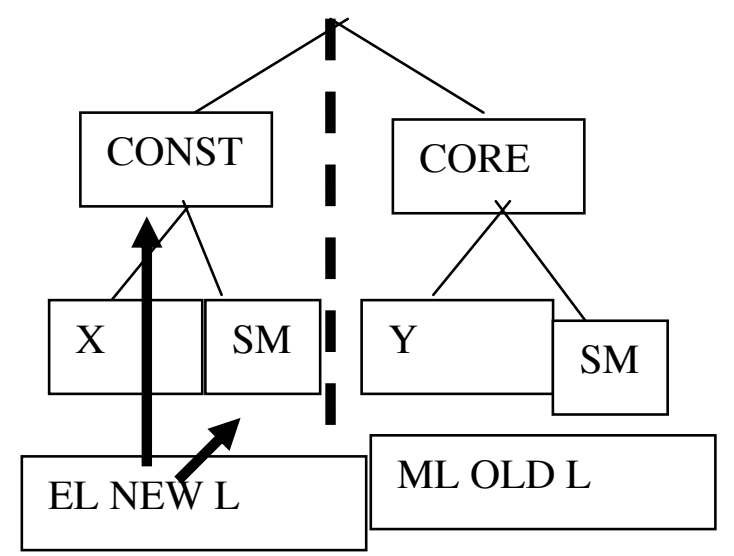

CORE - main part of clause dominated by Matrix Language

CONST - a constituent dominated by the other language

$\mathrm{SM}$ - system morphemes; X,Y other parts of core/constituent

\section{The split in polysynthetic languages}

\subsection{General}

In traditional Gurindji, there are obligatory pronominal enclitics which attach to either to a complementizer, an element termed a catalyst, or in second position in the clause, or to the verb in imperatives (McConvell 1996, to appear a, b). These bound pronouns disappeared rapidly and completely in Gurindji Kriol replaced by either Gurindji or Kriol free pronouns. Many languages in Australia, particularly Non-Pama-Nyungan,are polysynthetic in type in the following sense, of Baker's 'polysynthesis parameter':

Verbs must include some expression of each of the main participants in the event described by the verb (the subject, object and indirect object) (Baker 2001:111)

Polysynthetic languages appear according to some authors to show particular kinds of behaviour when they are involved in mixed language genesis. Bakker (2003:132) writes

\footnotetext{
${ }^{6}$ It seems likely that Gurindji also retains dominance of the $\mathrm{V}$ element where this is a Gurindji coverb acting as a verb in Gurindji Kriol. This would explain why such coverbs do not add the Kriol transitive marker -im in code-switching and Gurindji Kriol.
} 
typological considerations do play a role ...in the genesis of mixed languages. For instance, I have argued elsewhere (Bakker 1997) that the polysynthetic nature of the Cree verb prevents its break-up into a stem part and a morphological part...French verbal stems therefore cannot be inserted into a Cree verbal matrix... It appears that the verbs in a number of language, all of them showing person inflection in the verb are not easily used.

As part of an argument that mixed languages do not arise from code-switching, Bakker writes that 'mixed languages generally show insertional patterns, whereas CS patterns only show insertional patterns if the matrix language is agglutinative'. ${ }^{7}$

Bakker thus provides an explanation of why French stems cannot be inserted into Michif /Cree verbs based on their polysynthetic nature. This does not however explain why it is the Cree verbs with their built-in pronominal morphology which are retained in the mixed language while the NP's and PP's are French, and not the other way round. We now turn to further discussion of Michif and then to Modern Tiwi, an Australian mixed language arising from a polysynthetic language, traditional Tiwi.

\subsection{Michif}

Michif is the language of the Métis, a socially distinct mixed-race group in Canada: it is a mixed language drawn from French and Cree. Early reports indicate that it may have arisen via a stage of intrasentential code-switching. Bakker (1992) also reports on code-switching between other Algonquian languages and French and English, and the patterns of contemporary MontagnaisFrench code-switching are quite similar to the outcome in Michif, with a preponderance of French nouns entering the language, although in contrast to Michif, French verbs are also incorporated to some extent through a "helping verb” construction (Drapeau 1991).

In Michif, virtually all verbs, question words, personal pronouns and demonstratives are from Cree. Numerals and virtually all nouns, with their appropriate French articles or possessives, are from French, including gender distinctions. Prepositions and negative elements are more than 70\% from French and adverbs are more than $70 \%$ Cree. Cree nominal morphology is almost non-existent whereas Cree verbal morphology is extensive (Bakker 1992:236). The verb morphology of Michif is entirely Cree with the exception of some noun incorporation of French nouns and a very few French verb stems inflected in Cree fashion. The few affixes that do occur on Cree nouns (e.g. obviative) also occur on French noun phrases (which include French determiners and adjectives in the correct French position).

(18) Michif (Mixture of Cree and French; CAPS =French; l.c.=Cree)

[Bakker 1994:30]

PAR LA QUEUE apoci - pit - ew, kihtwam LE LOUP ase - kiwe - pahta - w by the tail inside.out pull he/him again the wolf backgo.home run he

'He pulled him inside out by the tail and the wolf ran home again.'

If one used Myers Scotton's scenarios here, Michif could be characterised as a frozen form of CS where the stabilisation occurred BEFORE turnover to the new language as ML. Cree dominates the basic grammar through the verb morphology which is at the heart of Cree grammar. Penetration of French verb stems into this structure is quite rare because of incompatibility between them and Cree affixes. Interestingly in the 'mixed' form of the related Canadian language Montagnais mentioned above (Drapeau 1991, 1995) insertion of French stems is much more common because

\footnotetext{
${ }^{7}$ This argument is critically examined in McConvell \& Meakins (2005)
} 
of the widespread use of a "helping verb" construction which allows the French infinitive to be inserted separately from the Cree verb morphology, e.g.

(19) Montagnais

ENGAGER nitu:ta:ku:ti

Hire they-did-me 'They hired me.'

This use of a non-finite verbal form with an inflecting ancillary verb is an extremely common strategy both in code-switching and in languages in contact around the world and it may well have been included in Myers-Scotton's 'compromise strategies' since it is in effect the use of a 'bare form' in the EL with a ML verb. ${ }^{8}$

Myers-Scotton (2002) argues that Michif polysynthetic verbs are so differently organised conceptually and grammatically from French or English that congruence is absent and compromise is difficult, so adoption of the Cree verb is forced. Dimmendaal (1998) in a proposal similar to mine (1997, 2002) puts emphasis on the 'head-marking' nature of Cree, and the inversion of the pattern found in Mednjy Aleut, and Myers-Scotton cites his proposal without objection. Bakker (2003) however puts more emphasis on the fact that the Cree verb morphology is inflectional rather than agglutinative to explain why it was adopted without being replaced or broken up.

What remains to be explained in Michif is the dominance not only of French lexicon but also of French grammar in the nominal morphology, including the use of French prepositional phrases. These could be regarded as EL islands in Myers Scotton's terminology, and she argues that the appearance of French EL islands is consistent with the MLF model. This does not however appear to provide any motivation for why what appears to be a quite specific area of grammar should be realised in the new language. This issue is reviewed in the next sections.

\subsection{Modern Tiwi}

In Australia, Modern Tiwi is a well-known example of radical linguistic change between generations. So great is the change that the older and younger people have difficulty in understanding each other although they believe that they are speaking the same language. While Traditional Tiwi is polysynthetic in type with very complex verb morphology, the middle-aged generation (speakers of Modern Tiwi, the variety to be examined here) has somewhat simplified the verb morphology. The young people's Tiwi of the next generation (Ultra-modern) has moved further in an analytical direction and towards English, but this variety will not be considered here. (Lee 1987: TT - traditional; MT -modern)

Traditional and Modern Tiwi

(20) Verbs

TT
(a) ngi-mini-pirni
he - me - hit
'He hit me.'

\footnotetext{
${ }^{8}$ I have argued that the complex verb constructions of traditional Gurindji and other neighbouring languages have achieved dominance precisely through such long-term contact interaction between languages in the region (McConvell \& Schultze-Berndt 2002).
} 
(c) yi-pirni

he/she:him.PST-hit

'She hit him.' (d)

kilim ji-mi arra

hit she-did him

(21) PPs in MT

TT

(a) ngu-mpu-nginji-kuruwala

I - NPST-you DAT-sing

'I will sing for you.'

(c) a-wuni-marri-kiji-ja manjanga heNPST-LOC-COMIT-stick-go stick

'He came with a stick.'

(e) kapala nga-ri-ma-jing-uriyi canoe weINCL-LINK-COMIT-IN-go

'We went in a canoe.'
MT

(b)
yi-kirimi jurra fu ngawa
hePST-make church for us
'He made a church for us.'
wokapat $a$-mpi-jiki-mi with layt
walk she-NPST-DUR-do with light
'She is walking with a light.'
yi-nuriyi ka mutika
hePST-come LOC car
'He came by car.'

Modern Tiwi retains marking of subject pronoun by means of verb prefix, and aspect marking on the verb. While some verb morphology is retained from the old language, English grammar takes over in the Prepositional Phrases, e.g. with layt, fu kapinaki. The complexity of Tiwi verbal morphology has suffered a drastic reduction: nearly all incorporated forms have been lost and pronominal objects, previously expressed in the verb, now appear as free forms, as in (20 b and d).

Traditional Tiwi had a number of free form verb stems which required a "helping verb" to go with them. This construction has now swept the board pushing out most of the non-compound verb forms and providing a welcoming environment for much borrowing of verb stems from English and Pidgin (as in the case of wokapat "walk" above).

From what Lee tells us about the history of the period, use of Pidgin English mixed with Tiwi as an interlanguage by mission staff was quite influential (Lee 1987:327-8), and pervasive codeswitching between Tiwi and forms of English was and is common on the Islands (Lee 1987:338ff).

As with the case of Michif and Montagnais, data on contemporary code-switching in related or typologically similar languages can give clues to possible scenarios leading to the Tiwi situation. The most apposite examples come from Non-Pama-Nyungan "prefixing" head-marking languages with complex verb morphology of polysynthetic type. From the limited data so far available (Leeding 1993) the pattern of CS used by young people, which is already tending towards a standardised style of "unmarked CS" in other Non-Pama-Nyungan languages, shows a strong tendency to retain verb morphology from the Aboriginal language while adopting vocabulary and nominal related features from English or Kriol.

(22) Burarra

Ngaypa/ ENOUGH MONEY /ngu-rrima-nga /TO BUY-IM /balaja

I I - have NPST buy food

'I have enough money to buy food.' 
(23) Burarra

Ngaypa /WAIT/ ngu-nirra nula /MY HUSBAND

I I - be for him

'I waited for my husband.'

The pattern for polysynthetic head-marking languages both in North Australia and North America seems to be for code-switching to retain the old language as a matrix, including old language verb forms, and a similar pattern to emerge when contact leads to a new mixed type of language.

\section{The 'Centre of Gravity’ Model}

\subsection{Head- and Dependent-Marking}

A better predictive model than that of Myers Scotton may be one in which the locus of the initial ML turnover in the grammar is selected by a typological feature of the old language. For the present I shall utilise the distinction made by Nichols (1987) between HEAD-MARKING and DEPENDENTMARKING languages. Polysynthetic North American languages with no nominal case marking like Cree are typical head-marking languages, as are most Non-Pama-Nyungan languages in Australia. Pama-Nyungan languages in Australia, on the other hand, with case marking on nominals and no pronominal marking on the verb are towards the dependent marking end of the spectrum. ${ }^{9}$

Different languages have different 'centres of gravity' for their grammatical systems. For headmarking verb-coding languages, the 'centre of gravity' is the verb; for dependent-marking nouncoding languages the 'centre of gravity' is in the nominal arguments. When a turnover of ML (as Myers Scotton calls it) is in progress the 'centre of gravity' resists the substitution of the new language longer. The corollary of this is the following:

\section{(24) Centre-of-Gravity Hypothesis of language split}

(a) head-marking verb-coding languages retain verbal grammar from the old language after nominal grammar has turned over to the new language; this situation when frozen between the two stages gives a ModernTiwi/Michif-type mixed language;

(b) dependent-marking noun-coding languages retain nominal grammar from the old language after verbal grammar has turned over to the new language; this situation when frozen between the two stages gives a Gurindji Kriol/Mednjy Aleut-type language.

These hypotheses roughly fit the situations of the languages discussed here: Cree and Tiwi are head-marking verb-coding languages and have yielded mixed languages Michif and Modern Tiwi respectively with the appropriate split. Gurindji is a dependent marking noun-coding language and has yielded the appropriate split in Gurindji Kriol. Mednjy Aleut is more problematic, although it clearly falls in the same outcome category as Gurindji Kriol.

\subsection{Problems with the Centre of Gravity Hypothesis}

The hypothesis is likely to contain a simplification since in its present form only one language in the pair of interacting languages is taken into consideration. Nevertheless if it does work reasonably

\footnotetext{
${ }^{9}$ Traditional Gurindji has bound pronouns as well as case-marking but these are hosted by a complementizer or in second position in the clause, quite different from the bound pronouns in polysynthetic verbs. These details cause some problems for the simple Head/Dependent marking distinction.
} 
well even with this simplification it could indicate that the type of the old language is of more importance than that of the new language.

While the Centre-of-Gravity generalization seems to be on the right track it may not exactly capture exactly the correct specifications of the types of languages which cause the split under discussion. 'Head marking' is a broader concept and this relates to what Nichols sees as the 'clause' domain of 'locus marking'. Further there is an apparent weakness in the 'head marking' definition in regard to languages which attach pronominal marking not to the verb but to a first constituent or complementizer like Gurindji. Nichols also classifies many languages, including most Australian languages, as 'double marking' in terms of head/dependent which does not provide good results and may indicate flaws in the procedure for classification. Baker's 'polysynthesis parameter' (cited above) may assist in defining verb-coding head-marking languages for our purposes.

There are also indications that the most significant element in determining the Matrix Language, and therefore understanding the splits which occur is the TAM system or what used to be called IP, with its head INFL or $\mathrm{I}^{10}$. This is the perspective I now turn to to try to improve the hypothesis.

\subsection{Typology of arrested turnover}

I adopt here Myers-Scotton's notion of mixed languages being cases of 'turnover' processes which are 'arrested' at some point in a formation of a composite ML. In most cases there is an 'old language' which the group traditionally spoke but to which a 'new' language is added to the bilingual repertoire. In my reading of Myers-Scotton there seems to be an implication that the old language originally provides the ML in code-switching, and that over time there is a turnover from that to the new language as ML, with, in some situations, intermediate composite ML stages. This may not be the way things happen for every case, as discussed in the previous section. For Gurindji, there is code-switching with both Gurindji ML and Kriol ML in different clauses in the 1970's but with a leaning towards Kriol (new language) ML but with some parts of the clause showing dominance of Gurindji morphosyntax.

This situation stabilizes in the mixed language as what I call by the formula N-INFL, shown diagrammatically in (25a) below ${ }^{11}$. A crucial question is the extent to which the grammatical type of the participating languages in this process determines the outcome. In the 'Centre of Gravity' hypothesis in its simplest form, the 'locus' type of the old language is determinant. Where a split occurs when the old language is dependent marking like Gurindji, the INFL (TAM) frame is taken from the new language but the case-marking frame may be retained from the old language.

The hypothesis can come in several forms. In the grammar-only variant, the presence of a dependent-marking language in the interacting pair alone can bring about the change, so that INFL$\mathrm{N}$ below (25b) can also freely occur. In a more restrictive 'language-sequence' variant of the hypothesis, it is crucial that the dependent-marking language is the old language so that this variant would rule out (25b) below-hence the asterisk. Another possible variant might regard the question of which language is adopted initially as the ML as a key independent variable. This is more problematic as it begs the question of why the ML choice-in effect an early but partial turnoverwas made, and this could involve complex socio-historical questions. It seems logical to focus first on the question of whether the grammar-only or language-sequence variants of the hypothesis stand up to empirical test. Finding an example of INFL-N would tend to falsify the language-sequence variant and add prima-facie credibility to the grammar-only version. I have not found a INFL-N

\footnotetext{
${ }^{10}$ Developments in Minimalism have mainly been in the direction of deconstructing INFL into a range of nested functional heads, called a 'cartography' in some recent work but the notion of an IP 'space' remains (Rizzi, ed., 2004).

${ }^{11}$ Here the notation KP is used for 'case phrase' dominating DP/NP, following Bittner \& Hale (1996).
} 
example but I have not looked very hard so far.

(25)The Infl-Nominal Split

\section{(a) N-INFL - Gurindji Kriol, ?Mednyj Aleut}

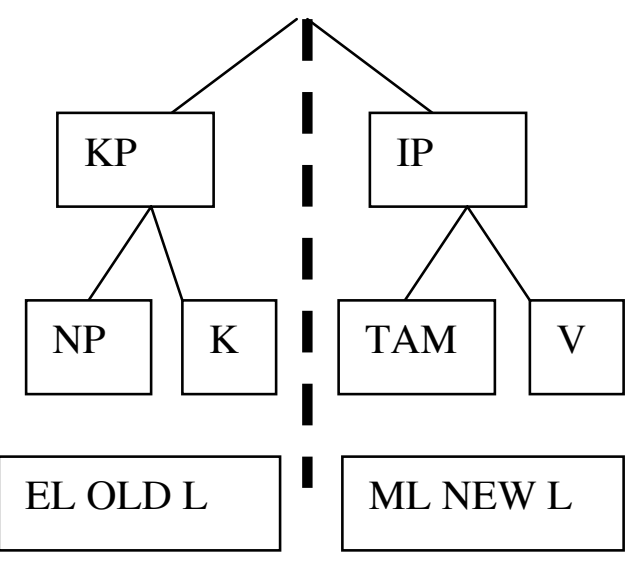

(b) INFL-N - *? for languagesequence variant

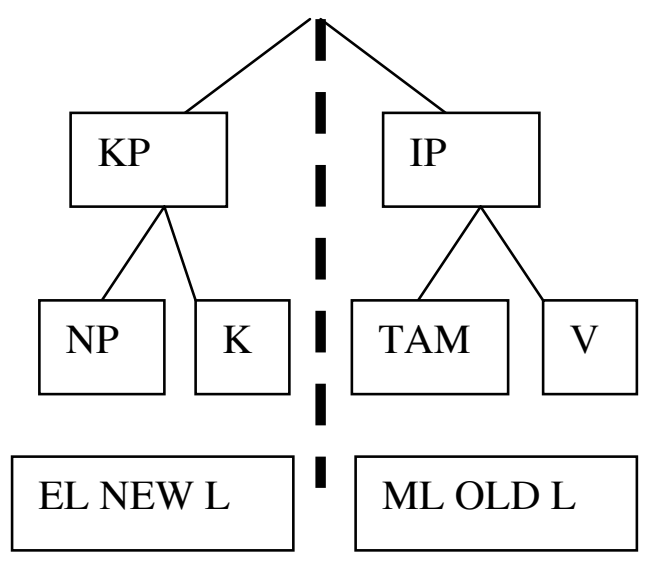

As I argued $(1997,2002)$ and also argued independently by Dimmendaal (1998) and MyersScotton (2002:263, citing Dimmendaal) the mixed language Mednyj Aleut is the product of a process and split essentially the same as that of Gurindji Kriol. One difference is that the INFL/TAM elements are represented by Russian elements suffixed to what are usually Aleut verb stems. However that is arguably a superficial difference since Kriol utilises preverbal TAM auxiliaries whereas many of the equivalent TAM elements are verbal suffixes. Mednjy Aleut, like Gurindji, appears to have adopted the new language Russian as the ML in the sense of provider of TAM, pronouns, word order, etc. early on but, like Gurindji, nominal morphology remained in the old language Aleut. Aleut adds a case where the grammar-only version of the hypothesis works, but does not contribute to resolving the question of whether language sequence is also relevant.

In the case of Michif and Tiwi, the alignment of the ML is with the old language in the sense that the verb which includes INFL/TAM is in the old language (Cree and Tiwi respectively), the obverse of that in Gurindji Kriol. This pattern is represented as V-N in (26b) below, in which the bound pronouns also are shown as part of the verb. As with the previous examples the inverse outcome with the polysynthetic verb coming from a new language and the nominal grammar from an old one (26a) is not exemplified here. It is possible that such cases exist but I have not done the extensive research required to unearth them. 
The Verbal-Nominal Split

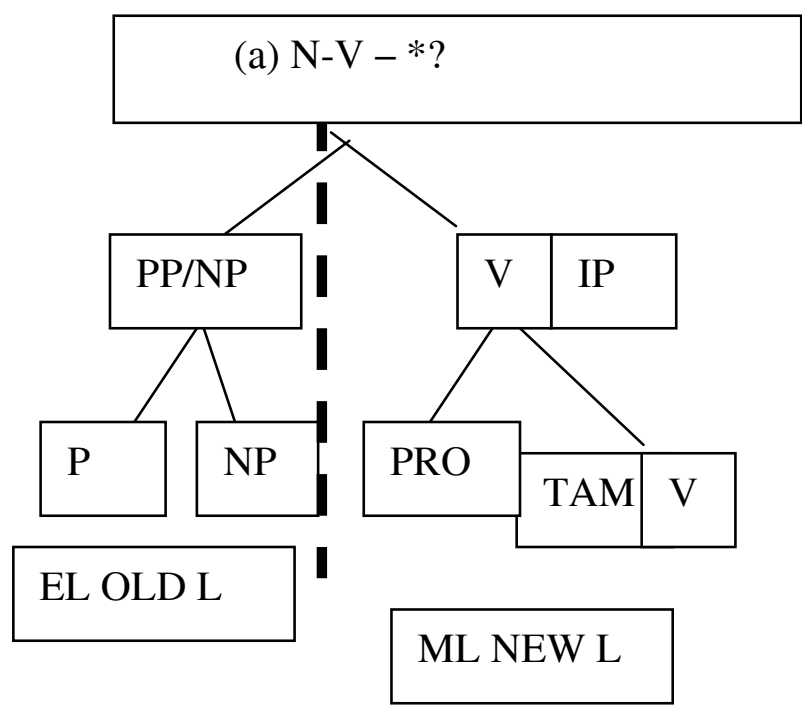

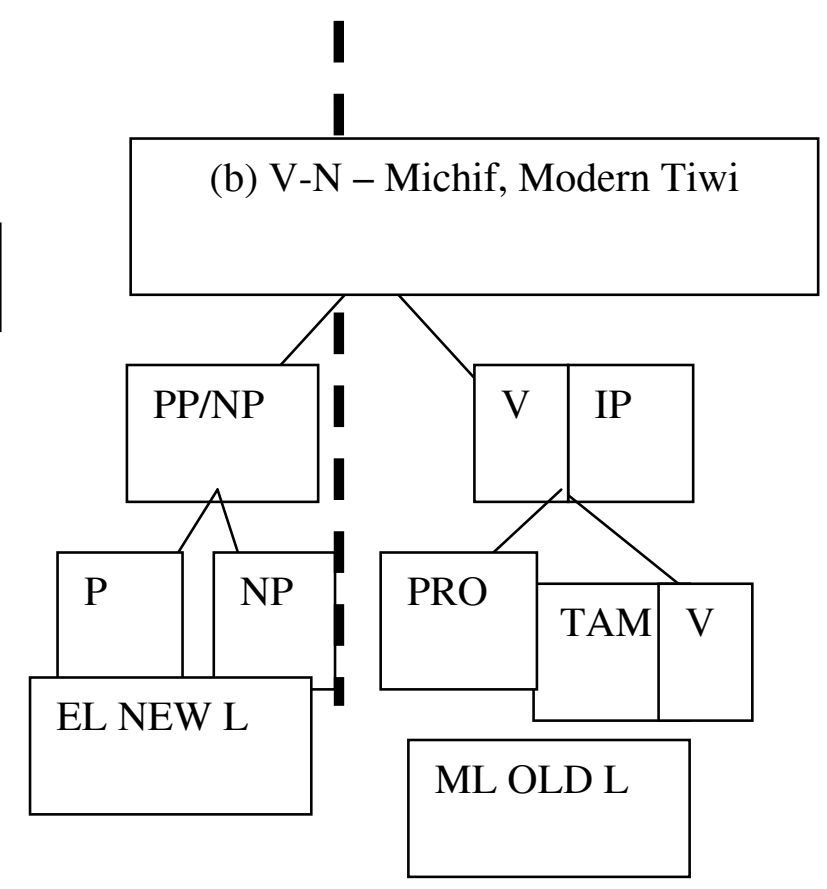

\subsection{Summary of convergence in the N-TAM and V-N Cases}

The diagrams (27) and (28) below summarise the main changes in the Gurindji and Tiwi transitions to a mixed language, respectively. In each case the outcome composite ML and mixed language is case (a) at the top; (b) represents the structure of the old component language, and (c) the new component language Kriol. The arrows going upwards show the components of the clause of each participating language which join to make up the new language. In each case this refers primarily to the system morphemes and syntax, not necessarily to the lexicon of the content items which may draw on either language. In some cases there is some mixture in the system morphemes, e.g. the Tiwi locative preposition $k a$ also enters the preposition set alongside English prepositions in Modern Tiwi. Only the simple intransitive paradigm of verbs is inherited into Modern Tiwi from the old language and new compounds make up the rest of the lexicon; the loss of other crossreferencing pronouns apart from the subject is marked by the symbol 


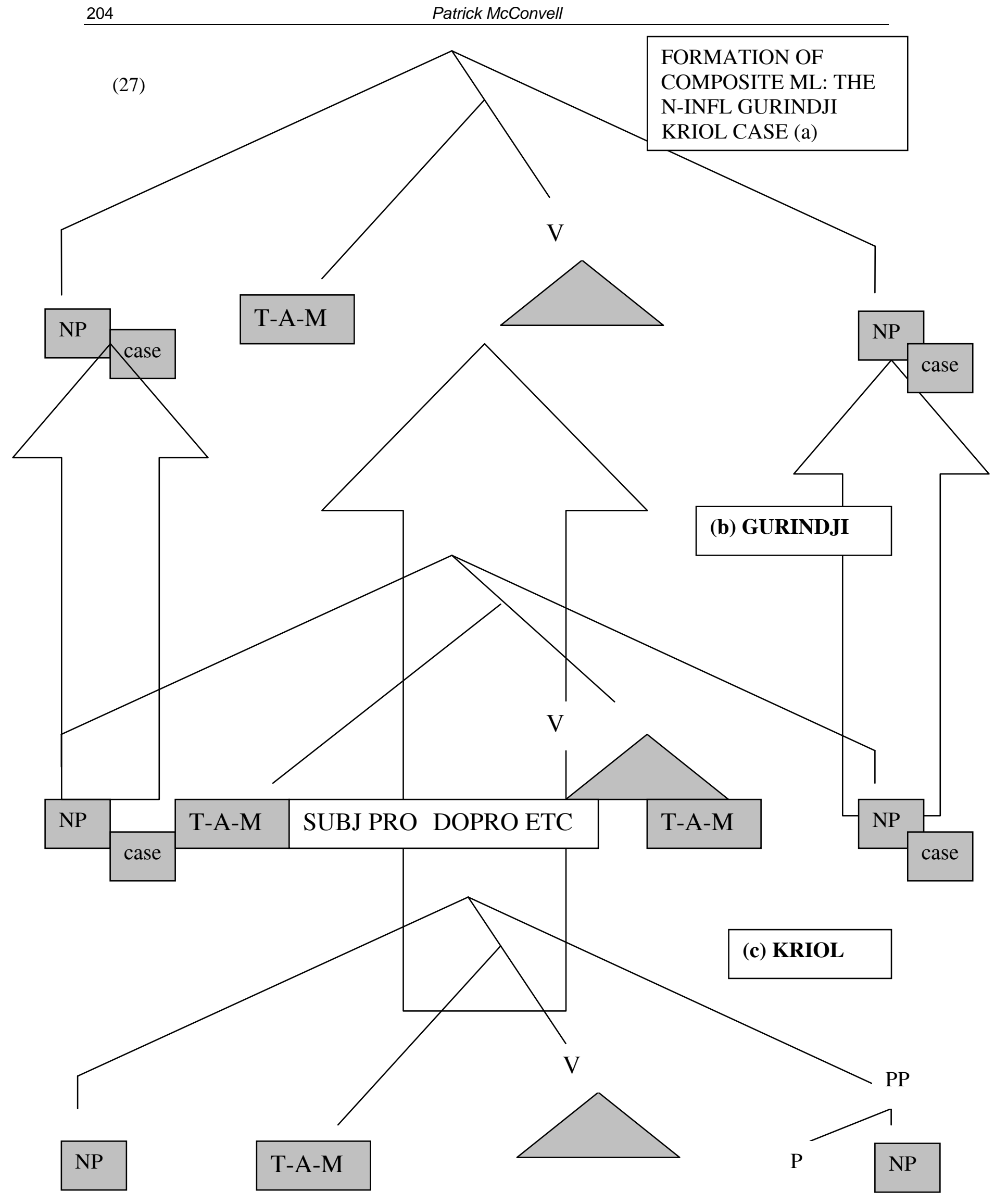


(28)

FORMATION OF

COMPOSITE ML: THE

V-N MODERN TIWI

CASE (a)

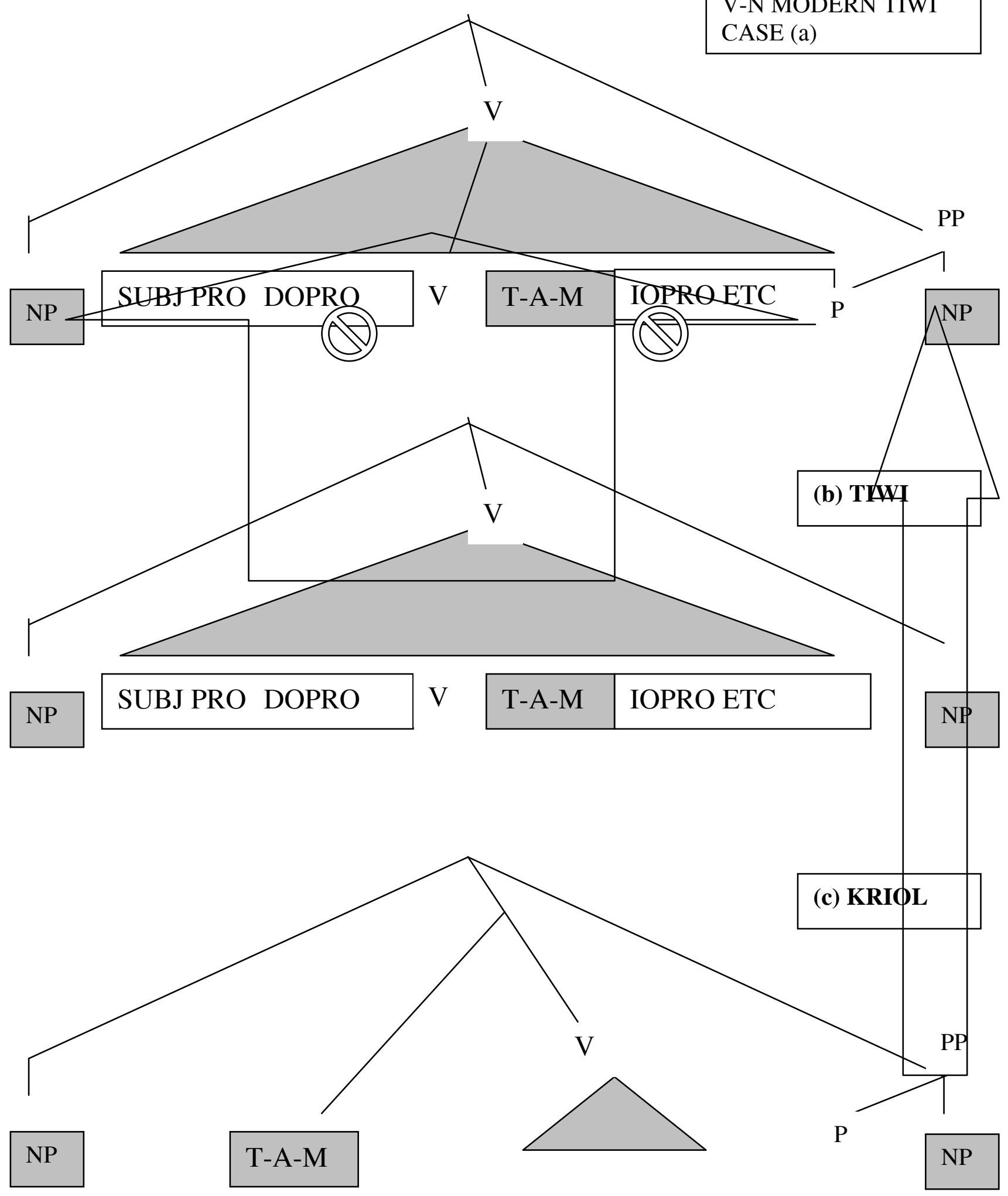




\subsection{Simplification of verbal pronominal morphology in polysynthetic languages}

In the case of the development of Gurindji Kriol, the loss of pronominal enclitics was attributed to the replacement of the Gurindji INFL (TAM) system by the Kriol INFL system. In the case of Michif the Cree verb morphology including the pronominal elements are largely retained.

Modern Tiwi however, as illustrated in the previous section, has also undergone some radical simplification in the verb morphology. Of the long and complex forms including pronominal, TAM and other affixes only a single simple intransitive paradigm remains. Rather than object pronouns being found in the verb, they occur as (Tiwi) free pronouns following the verb. Since Michif did not undergo this kind of process it cannot be a direct result of the V-N split process as so far discussed.

There are parallels with what happened to Tiwi elsewhere however. In the nineteenth-century pidgin "Broken Oghibbe-way" (Nichols 1995) only subject bound pronouns are retained and object pronouns are realised by free pronouns following the verb. The old language Ojibwe, an Algonquian language, by contrast, has both subject and object markers on the verb. This is the same change as occurred in Tiwi. The examples are from Bakker (1995:3-2), cited by Bresnan

(29) Broken Oghibbeway:

'He fears me.'

O $\quad$-kot -aan niin.

3sg.an-fear-3. $1 \mathrm{sg}$

(30) Ojibwe

$\mathrm{Ni} \quad-\mathrm{gos} \quad-\mathrm{ig}$

1 sg -fear- inv.3sg.subj

There are many more, and more complete, examples of loss of bound pronouns (eg McConvell 1981) at least some of which may be attributable to language contact but are often placed in the class of 'pidginisation'. In postings to the Creolist (McConvell 1997) I drew attention to the fact that Yimas Pidgin in Papua New Guinea replaces all verbal pronominal morphology with free pronouns. This is what happens in other 'pidgins' around the world, but in this case the 'Pidgin' is not a colonial product and no external lingua franca is involved. The language developed as a result of interaction and trade between the Yimas and their neighbours the Arafundi, and both of these languages are polysynthetic with bound pronouns within the verb. Possibly significant in this outcome is the fact that the pronominal elements on the verb are prefixes in Yimas and suffixes in Arafundi. There is therefore a lack of congruence of the systems in morpheme order and one might predict from that a replacement by free pronouns using a variation on the MLF model (cf. Jake 1994).

(31) Yimas Pidgin:

'I hit him.'

Ama min namban kratiki-nan.

1sg 3sg toward hit-nonfut 
Yimas

(32) Na-ka-tupul.

3sgO-1sgS-hit

(Foley 1988:171)

There seems to be a widespread and systematic process occurring here in language contact involving partial or total replacement of bound pronoun systems with free pronouns. At the present stage of knowledge it would seem to be a separate phenomenon from the 'centre-of-gravity' hypothesis discussed in the rest of the paper, although the possibility that connections can be made should not be ruled out.

\section{Conclusions and historical predictions}

\subsection{Contexts of mixed language genesis}

This paper has shown that there is at least one well-documented case of a transition from codeswitching to a mixed language which has arisen in recent times. There are others in Australia and elsewhere where the evidence could be collected to support this scenario.

It is not claimed that all contact-induced change producing a degree of hybridity is due to codeswitching. One of the important tasks is to discover the circumstances in which it occurs, and the signatures of its previous occurrence as opposed to those of other types of contact.

Bakker (2003), in the context of an argument against mixed languages arising from codeswitching (CS), states that code-switching is only found where both languages involved in the CS are held in esteem by the speakers. No references are cited to back up this assertion. Similar statements have certainly been made, e.g. that a high degree of political competition between languages and their speaker groups militates against CS, e.g. the case of Castilian Spanish and Catalan. This seems to be a reasonable first approximation to a generalisation but it is curious that little research has been done to confirm or tighten up this hypothesis.

Similarly socio-historical arguments have been made about what kind of situation leads to mixed language genesis. While the notion that a new social group (ethnogenesis) must be involved is too strong, there are interesting parallels between the cases. It would seem that many involve a turn away from a potential fate of simply being a low status group of uncertain identity to grasping a specific identity bound up with the new language. This is not incompatible with code-switching between the old and new language in the transitional period. ${ }^{12}$

\section{2. ‘Centre of Gravity’ Hypothesis}

A 'Centre-of-Gravity' Hypothesis has been proposed to explain the nature of the mixed language outcomes, based on the head/dependent marking parameter which yields a verbal or a nominal centre of gravity respectively. The centre of gravity retains the grammar of the old language whereas the parts of the clause outside the centre of gravity are attracted to the grammar of the new language.

The hypothesis has also been critically examined and modified, taking into account the notions of turnover and composite matrix language of Carol Myers-Scotton and her group. Rather than emphasising the verb, the language of INFL especially the Tense-Aspect-Mood elements was considered a key to the matrix language and the verb gains significance to the extent that TAM

${ }^{12}$ I have argued that the development of mixed languages in Australia, as opposed to more direct and complete language shift to a creole, is related to the existence of a single traditional language in the community as opposed to multiple languages (McConvell 2007, 2008). 
elements are part of it.

\subsection{Contact between different locus-marking types}

The type of split between Nominal on the one hand, and Verbal elements or INFL (tense-aspectmood) elements on the other, is not particularly common in the history of languages perhaps, but is attested in other kinds of language pairs apart from Australian head and dependent marking traditional languages, and creoles which are generally neutral for the head/dependent feature. We have already discussed Michif and Mednyj Aleut. In North-Western China, Chinese dialects (especially Mandarin), which are also neutral regarding head/dependent, have interacted with local agglutinative Turkic languages to produce hybrid languages (Hezhu, Dongxiang and Tangwang) which have generally Chinese vocabulary but case suffixes borrowed from the Turkic languages (Wurm et al. 818-819), in a similar fashion to Gurindji Kriol, taking case morphology from dependent-marking Gurindji ${ }^{13}$

Apart from documentation of further contemporary and historical cases of mixed language genesis, it would be valuable to look for languages to see if tell-tale signatures of this kind of development can be found in modern or ancient languages. This section simply sketches some notes towards a possible research program at this stage.

In the case of the kinds of development we have looked at here, this would involve finding cases where

(a) case-marking and other nominal morphology come from a different source language or family of languages from the TAM system or other verbal elements, in the case of a $\mathrm{N}$ INFL split; or

(b) prepositions (or postpositions) come from a different source language or family of languages from the verbal morphology in the case of a V-N split.

To qualify to be attributed to the kind of hybridization discussed, these splits in origin would have to be reasonably throughgoing in the languages concerned, attributable to systemic merger of grammatical systems, not just one-off borrowing of individual elements like case-markers and prepositions. Prepositions are known to be borrowed for instance from Spanish into Indigenous American languages (Field 2002:158-9 ; Hill \& Hill 1986:147ff; Harris \& Campbell 1995:124,132), and from Mon-Khmer languages into the Austronesian Chamic group (Thurgood 1999:246-7) without necessarily leading to the conclusion that a V-N split has occurred ${ }^{14}$

Some of this research could perhaps be carried out by using the World Atlas of Linguistic Structures (WALS; Haspelmath et al. 2005) resource, initially at least. One of the typological

\footnotetext{
${ }^{13}$ There are some contact languages reported in which Turkish is the new language, which supplies all or some of the TAM and pronominal affixes on the verb, a situation reminiscent of the attachment of Russian TAM elements to the Mendyj Aleut verb. One such is the dialect of the Geygel nomads, a Romani-Turkish mixed language (Bakker 2003). A different kind of case is that of the addition of Turkish inflections on Greek verb in the Semendere Cappadocian variety of Asia Minor Greek. Here the Turkish suffixes are added to forms which are already inflected for subject agreement in Greek-a case of 'double marking', e.g. ketunmist-ik 1 pl ketunst-iniz 2pl (Thomason \& Kaufman 1988:219; Janse 2002). This may indicate that Turkish is 'double marking' rather than purely 'dependent marking'.

${ }^{14}$ This possibility should not be ruled out a priori, but should be investigated language by language. In many cases however only a limited number of prepositions is borrowed, and, as Field notes in relation to Mexicano, there are already preposition-like elements in the target language which perhaps provided a model for this development see McConvell (2005) on the significance of preexisting models in facilitation of grammatical loans). The same is true of Chamic.
} 
features in that data base is the 'locus' or head/dependent marking parameter of clauses. On an initial search for different types which were located fairly close together and could have yielded contact varieties, these were some of the pairs I found. No further work has been done on this at this stage but it would be interesting to take this further.

\section{Pairs of contrasting settings for clause locus marking in neighbouring areas in WALS}

Double \& dependent

Greek \& Turkish

Ingush \& Lezgian

Double \& head

Georgian \& Abkhaz

Dependent \& none

Ik \& Lugbara

Semai \& Indonesian

Japanes \& Ainu

Asmat \& Kombai

Head \& none

Lango \& Lugbara

Achenese \& Nicobarese

Tanglapui \& Lamaholot

Of course, the relevant transition to a mixed language with the type of grammatical split we have been discussing could well have occurred some hundreds or thousands of years ago so inspection of current languages in a region may only rarely provide clues to where such mixed languages might appear, as the languages may have moved and/or changed grammatical type.

Further, as outlined in this paper, I am critically reviewing the the notion that head-dependent marking is the relevant one for this research as the notion of location of INFL or some similar concept is looking more promising. Nevertheless since the typological surveying has been done based on head/dependent marking, and it does capture the relevant kinds of languages involved in the split hybridity outcomes we are examining to a reasonable extent, it would provide a heuristic at least for the initial stages of research into this question.

\section{References}

Baker, Mark. 2001. The Atoms of Language: the mind's hidden rules of grammar. New York: Basic Books.

Bakker, Peter. 1992. A language of our own: the genesis of Michif, the mixed Cree-French language of the Canadian Metis. Ph.D dissertation, University of Amsterdam.

Bakker, Peter. 1995. Pidgins. In J. Arends, P.Muysken \& N.Smith (eds.) Pidgins and creoles; an introduction, 25-39. Amsterdam: John Benjamins, Creole Linguistic Library 15. 
Bakker, Peter. 1997. A language of our own: the genesis of Michif, the mixed Cree-French language of the Canadian Metis. New York: Oxford University Press. (based on Ph.D dissertation 1992).

Bakker, Peter. 2003. Mixed languages as autonomous systems. In P. Bakker \& Y. Matras (eds.) The mixed language debate: theoretical and empirical advances, 107-150. Berlin: Mouton de Gruyter.

Bakker, Peter \& Maarten Mous (eds.) 1994. Mixed languages: 15 case studies of language intertwining. Amsterdam: IFOTT.

Bittner, Maria \& Kenneth Hale. 1996. The Structural Determination of Case and Agreement. Linguistic Inquiry 27:1-68.

Bresnan, Joan. 2001. Pidgin genesis in Optimality Theory. In M. Butt \& T.H. King (eds.) LFG98 Proceedings.Stanford: CSLI.

Charola, Erika. 2002. Verb phrase structure in Gurindji Kriol. Unpublished Honours thesis: University of Melbourne.

Dalton, L., S.Edwards, R.Farquharson, S.Oscar \& P. McConvell. 1995. Gurindji Children's language and language maintenance. International Journal of the Sociology of language 113:83-96.

Drapeau, Lynn. 1991. Michif replicated: the emergence of a mixed language in Northern Quebec. Paper presented at the 10th International Conference on Historical Linguistics, Amsterdam.

Drapeau, Lynn 1995 Code-switching in caretaken speech and bilingual competence in a native village of Northern Quebec International Journal of the Sociology of language 113:157164.

Field, Fredric. 2002. Linguistic borrowing in bilingual contexts. Amsterdam: John Benjamins.

Foley, William. 1988. Language birth: the sociolinguistics of pidginization and creolization. In F. Newmeyer \& R. Ubell (eds.), Linguistics: The Cambridge Survey, 162-83. Cambridge: Cambridge University Press.

Golovko, Evgenij V. 1994. Copper Island Aleut. In Bakker \& Mous (eds.) 113-121.

Haspelmath, Martin, M. Dryer, D. Gil \& B. Comrie. 2005. World Atlas of Language Structures. Oxford: Oxford University Press.

Jake, Janice. 1994. Intrasentential codeswitching and pronouns: on the categorial status of functional elements. Linguistics 32:271-98.

Janse, M. 2002. Aspects of Bilingualism in the History of the Greek Language. In J.N. Adams, Mark Janse \& Simon Swain (eds.), Bilingualism in Ancient Society. Language Contact and the Written Word, 332-390. Oxford: Oxford University Press.

Lee, Jennifer. 1987. Tiwi Today. Canberra: Pacific Linguistics.

Leeding, Velma. 1993. Notes on code-switching in Aboriginal languages. Ms. Batchelor College.

McConvell, Patrick. 1981. How Lardil became Accusative. Lingua 55:141-179 
McConvell, P. 1988. Mix-im-up:Aboriginal code-switching, old and new. In M.Heller (ed.) Codeswitching: anthropological and sociolinguistic perspectives, 97-124. Berlin: Mouton de Gruyter.

McConvell, Patrick. 1996. The Functions of Split-Wackernagel Clitic Systems: Pronominal Clitics in the Ngumpin languages. In A. Halpern \& A. Zwicky (eds.) Approaching second: second position clitics and related phenomena, 299-332. Stanford: CSLI.

McConvell, Patrick. 1997a. Code-switching and radical change outcomes in dependent-marking and head-marking Australian languages. Paper to Tilburg workshop on Code-switching.

McConvell, Patrick. 1997b. MLF and free/bound pronouns. Posting to the CreoLIST, May 28, 1997. On-line, University of Stockholm: www.ling.su.se/Creole/CreoLIST/ .

McConvell, Patrick. 1997c. Yimas pidgin: addendum. Posting to the CreoLIST, May 29, 1997. Online, University of Stockholm. www.ling.-su.se/Creole/CreoLIST/ .

McConvell, Patrick. 2002. 'Mix-im-up' speech and emergent mixed languages in indigenous Australia. Proceedings of SALSA 2001. Texas Linguistic Forum 44.1-2:328-349.

McConvell, Patrick. 2005. Language contact interaction and possessive variation. Monash University Working Papers in Linguistics 5.2:87-105.

McConvell, Patrick. 2007. Language Ecology As Determinant Of Language Shift Or Language Hybridity: Australian Aboriginal Cases. International Symposium on Bilingualism, Hamburg.

McConvell, Patrick. 2008. Language mixing and language shift in indigenous Australia. In G. Wigglesworth \& J. Simpson (eds.) Children and language in multilingual communities, 205-225. London: Continuum.

McConvell, Patrick \& Mary Laughren. 2004. Ngumpin-Yapa Languages. In H. Koch \& C. Bowern (eds.), Australian Languages: Classification and the Comparative Method, 151-178. Amsterdam: John Benjamins.

McConvell, Patrick \& Felicity Meakins. 2005. Gurindji Kriol: a mixed language emerges from code-switching. Australian Journal of Linguistics 25.1:9-30.

Matras, Yaron. 2003. Mixed languages: re-examining the structural prototype. In Bakker, P. \& Matras, Y (eds.) The Mixed Language debate, 151-175. Berlin: Mouton de Gruyter.

Meakins, Felicity. 2007a. Alternational code-switching and mixed language genesis. Paper to Australian Languages Workshop, Pearl Beach.

Meakins, Felicity. 2007b. Case-marking in Contact: the development and Function of Case Morphology in Gurindji Kriol, an Australian mixed language. Ph.D thesis, University of Melbourne.

Myers-Scotton, Carol. 1993. Duelling languages. Oxford: Clarendon.

Myers-Scotton, Carol. 2002. Contact linguistics: bilingual encounters and grammatical outcomes. Oxford: Oxford University Press. 
Nichols, John D. 1995. The Ojibwe verb in 'Broken Oghibbeway’. Amsterdam Creole Studies 12:118.

Nichols. Johanna. 1987. Head-marking and Dependent-marking Grammar. Language 62.1:56-119.

Nichols, Johanna \& Balthasar Bickel. 2005. Locus of Marking in the Clause. In Haspelmath et al., 98-101, http://wals.info/feature/23?v1=cd00\&v2=c00d\&v3=c909\&v4=cfff\&v5=cff0\&tg_format $=\mathrm{m}$ ap\&lat $=5.5 \& \operatorname{lng}=152.58 \& \mathrm{z}=2 \& \mathrm{t}=\mathrm{m}$

O’Shannessy, Carmel. 2004. Light Warlpiri: a new language. Australian Journal of Linguistics 25.1:31-57.

O’Shannessy, Carmel. 2006. Language contact and child bilingual acquisition: learning a mixed language and Warlpiri in Northern Australia. Ph.D thesis Max-Planck Institute of Psycholinguistics, Nijmegen/University of Sydney.

Rizzi, Luigi (ed.).2004. The Structure of CP and IP: the cartography of synctactic structures Vol. 2 Oxford: Oxford University Press.

Thomason, Sarah \& Terrence Kaufman. 1988. Language contact, creolization and genetic linguistics. Berkeley: University of California Press.

Thurgood, Graham. 1999. From Ancient Cham to Modern Dialects: Two Thousand Years of Language Contact and Change. Honolulu: University of Hawai'i Press.

Van Coetsem, Frans. 2000. A general and unified theory of the transmission process in language contact. Heidelberg: Universitätsverlag, C. Winter.

Winford, Donald. 2005. Contact-induced changes: Classification and processes. Diachronica 22.2:373-427.

Winford, Donald. 2007. Some Issues In The Study Of Language Contact, Journal of Language Contact, Thema 1: 22-40.

Wurm, Stephen Adolphe, Peter Mühlhäusler \& Darrell T. Tryon. 1996. Atlas of Languages of Intercultural Communication in the Pacific, Asia, and the Americas. Vol.II.2 Berlin: Mouton de Gruyter. 